\title{
Legal Understanding of Persons with Disabilities Regarding Fyy Accessibility in Performing Worship in the Mosque
}

\author{
Pudji Astuti 1,*, M Turhan Yani ${ }^{2}$, Eny Sulistyowati ${ }^{3}$, Muh. Ali Masnun ${ }^{4}$
}

\author{
1,2,3,4 Universitas Negeri Surabaya, Indonesia \\ *Corresponding author. Email: pudjiastuti@unesa.ac.id
}

\begin{abstract}
The rights of persons with disabilities related to the fulfillment of ease of accessibility in carrying out worship in mosques have not been fulfilled by mosque managers as well as the government which has the obligation to fulfill these obligations. Various laws and regulations have guaranteed this right. However, do people with disabilities understand that they have the right to have easy access to mosques when performing their prayers? What factors influence their understanding? This research is socio legal type. Research data collection is done through interviews, observation and documentation. Research informants are persons with disabilities. Data were analyzed qualitatively. The results showed that the majority of people with disabilities understand the legislation on accessibility in carrying out worship in mosques. They gain understanding from the organizations of persons with disabilities that they participate in.
\end{abstract}

Keywords: Persons with disabilities, Ease of accessibility, Mosque

\section{INTRODUCTION}

The constitutional rights of persons with disabilities, especially those related to the fulfillment of ease of accessibility in carrying out worship in mosques, have not been fulfilled by mosque managers as well as the government which has the obligation to fulfill these obligations. Persons with disabilities are categorized as a vulnerable group of people. Vulnerable groups like other citizens have the right to protection. One form of protection is the ease of accessing the mosque.

The construction of infrastructure facilities that have accessibility for persons with disabilities is a form of respect, protection, and fulfillment of the rights of persons with disabilities. This is related to the existence of "limitations" for persons with disabilities so that they need convenience to carry out their activities. In this case, "limitations" are related to the limited function of motion, intellectual function, mental function, and sensory/sensory functions in carrying out daily life.

Persons with disabilities are part of marginalized communities who are excluded in the national development process. They do not get a proper place and position in the social life of society. In the process of planning and designing buildings and the environment in various areas, the diffable community always goes unnoticed. Lack of attention to persons with disabilities due to the complexity of social, cultural, and legal factors. Persons with disabilities are only considered as second-class citizens and are not considered to be able to make an important contribution to the overall development process [1].

Law Number 8 of 2016 concerning Persons with Disabilities (hereinafter referred to as the Law on Persons with Disabilities) regulates various rights of persons with disabilities, one of which is religious rights related to easy access to use places of worship. In addition to the Law on Persons with Disabilities, Law Number 39 of 1999 concerning Human Rights also guarantees every person with disabilities to obtain facilities related to the provision of facilities and facilities for smoothness, security, health and safety. The government has the obligation and responsibility to ensure the implementation of these rights as a form of protection and enforcement of human rights.

Regarding the rights of persons with disabilities to have easy access to use places of worship, especially in mosques, the fact is, persons with disabilities do not have access to public facilities and services. The Executive Board of Nadhatul Ulama stated that a large number of places of worship are not friendly enough to support the rights of persons with disabilities to worship in mosques. This condition certainly hinders, especially for people with physical disabilities, who use assistive devices such as canes and wheelchairs. Many ablution facilities in mosques are less accessible [2].

Based on the 2015 Supas results, the highest percentage of the population aged 10 years and over with disabilities in 4 (four) provinces in Java is in East Java Province. The percentage can be seen in the table below. 
Table 1 Percentage of Population Age 10 and Over with Disabilities inFour Provinces in Java

\begin{tabular}{cccc}
\hline No. & Province & $\begin{array}{c}\text { Percentage of } \\
\text { Non-Disabled } \\
\text { Population }\end{array}$ & $\begin{array}{c}\text { Percentage of } \\
\text { Population with } \\
\text { Disabilities }\end{array}$ \\
\hline 1 & East Java & 90.60 & 9.40 \\
\hline 2 & Central Java & 91.38 & 8.62 \\
\hline 3 & West Java & 91.83 & 8.17 \\
\hline 4 & Yogyakarta & 91.85 & 8.15 \\
\hline
\end{tabular}

Sources : Supas in Year 2015 [3]

Even though in percentage terms, people with disabilities are lower than people without disabilities, they have rights that should be respected and fulfilled. Do persons with disabilities know and understand that they have the right to have easy access to mosques when performing their prayers as regulated in the laws and regulations? Knowledge of statutory regulations is knowledge of a set of laws in the form of regulations regarding certain life. Furthermore, legal understanding is a number of information owned by a person about the content, purpose and benefits of the regulation for himself.

Based on the above, the issues raised are: how do people with disabilities understand the laws and regulations governing the ease of accessibility in carrying out worship in mosques?

\section{METHODS}

This research is a sociolegal type, which is to examine textually the articles in legislation and policies, then critically analyze and explain their meanings and implications for marginalized communities. This research is located in Surabaya City and Sidoarjo Regency.

The data required in this study consists of (1) primary data obtained by a) interviews with persons with disabilities; and b) observations at several jami' mosques; (2) secondary data which includes a) primary legal materials, namely Law Number 11 of 2020 concerning Job Creation, Law Number 8 of 2016 concerning Persons with Disabilities, Law Number 28 of 2002 concerning Buildings, Regulation of the Minister of Public Works and Public Housing Number 14 of 2017 concerning Requirements for Ease of Building Buildings; b) secondary legal materials in the form of literature or legal articles in journals or proceedings relating to the problem under study; and c) non-legal materials in the form of annual reports from related institutions.

Research data collection was carried out through (1) interviews with persons with disabilities; (2) observation by observing the existence of access at the mosque; and (3) documentation. Research informants are persons with disabilities. The data will be analyzed qualitatively.

\section{RESULTS AND DISCUSSION}

Accessibility as stated in Article 1 point 8 of the Law on Persons with Disabilities is the facilities provided for persons with disabilities in order to realize equal opportunities. One form of opportunity is the opportunity to worship at the mosque. Basically, there is accessibility in the form of physical and non-physical. Lubis, Edi Chandra Julian [4] stated that physical accessibility can be seen, held and felt. Physical accessibility in the form of convenience in the building. Nonphysical accessibility relates to how information, communication and technology can be used or understood by persons with disabilities.

Informants with disabilities in this study have disabilities related to the functions of the five senses, namely being unable to see (blind); and disability related to impaired movement function due to amputation or experiencing withered paralysis (folio). Of course, the types of disabilities experienced by people with disabilities require different accessibility facilities. Research results from PBNU and the Center for Disability Studies and Services Universitas Brawijaya (PBNU, 2019) show that people with disabilities are often troubled by the shape of buildings that are designed without considering the needs of people with disabilities.

The majority of persons with disabilities are aware of the laws and regulations relating to the ease of accessibility in mosques. Knowledge of whether or not there are rules governing the actions that he is doing or is currently paying attention to is a cognitive style [5]. They know and understand these regulations from the organizations of persons with disabilities that they follow. These organizations are the Indonesian Blind Association, the Indonesian Association of Persons with Disabilities and the Indonesian Diffable Motorcycle. This is in line with what was stated by B. Bierstedt [6] that a person is aware of his life if there are regulations that provide benefits for him. The regulation benefits people with disabilities so that they try to understand it. Understanding is obtained from various activities held by various organizations of persons with disabilities and the government. Activities in the form of socialization, workshops and focus group discussions.

These activities are a form of "legal literacy program". As stated by Soetandjo W [5] that the legal literacy program is a program to make citizens legal literate. The existence of various activities participated in by persons with disabilities made them understand various laws and regulations relating to the ease of accessibility in mosques.

Furthermore, Schuler and Kadiargam Rajashingham [5] argue that the end of legal literacy is to teach knowledge and move an understanding of the law which in the end will favor the interests of the people who have been placed in a marginal position. Through legal literacy, people with disabilities who have been positioned as marginal groups understand that their right to accessibility in mosques is protected by laws and regulations. The informants of this research understand the forms of accessibility in the mosque.

The majority of informants understand that the purpose of the regulation is to protect their rights. They understand that the form of protection related to the ease of accessibility in mosques is based on the type of disability experienced. Those who are blind understand accessibility in the form of a "sign" that makes it easier for them to enter the mosque and which shows the Qibla direction, as well as a place to perform ablution. For people with physical disabilities, they want a 
place to enter the mosque and a place for ablution that has accessibility, especially for wheelchair users, and a place for ablution. The accessibility understood by the informants was limited to physical accessibility. As stated by Lubis, Edi Chandra Julian [4] that physical accessibility can be seen, held and felt. Physical accessibility in the form of convenience in the building.

All informants work in the private sector as street vendors, basic food shops and electronic service providers. The informant's education level is Senior High School. The gender of the majority of informants is male. However, they are very understanding. This is not in line with the opinion of Sudjana (2004) that the understanding of community members has a relationship with the level of education and work. Low social status means low understanding and medium social status means moderate understanding.

There were informants who voiced the rights of their people by praying in several mosques to find out the accessibility of facilities in mosques. Furthermore, the person concerned voiced his rights to the mosque management. When the government conducts focus group discussions related to the legislation in question, the informant voices "what he has seen". Here people with disabilities have the courage to voice their rights. This agrees with the opinion of Soetandjo W [5] that awareness of rights will raise the courage of community members to question their legal rights before state authorities which can be expected to encourage transparency and accountability of public officials in carrying out government duties.

Sabian [7] stated that the law as a regulation that regulates society will be meaningful if it is supported by a strict sanction system. Legislation related to accessibility provides sanctions for mosque managers if they do not meet the requirements for ease of accessibility for persons with disabilities in carrying out worship in mosques. Types of sanctions imposed are administrative sanctions. However, people with disabilities do not understand the administrative sanctions imposed on mosques that do not provide easy accessibility in mosques. Sanctions in administrative law as a tool of power that are public law are used by the government as a reaction to disobedience to the obligations contained in the norms of state administrative law [8]. In fact, so far the government has never imposed administrative sanctions on mosque managers.

\section{CONCLUSION}

The results showed that the majority of people with disabilities understand the legislation on accessibility in carrying out worship in mosques. They gain understanding from the organizations of persons with disabilities that they participate in.

\section{ACKNOWLEDGMENT}

The authors would like to thank the Faculty of Social Sciences and Law for facilitating this activity so that the authors get many benefits for scientific development.

\section{REFERENCES}

[1] R. R. dan B. Harahap, "Perlindungan Hukum terhadap Penyandang Disabiltas Menurut Convention on The Rights of Persons with Disabilities (CRPD)," J. Inov., vol. 8 , no. 2,2015

[2] P. B. N. U. (PBNU), "Fikih Penguatan Penyandang Disablitas.," Jakarta: PBNU dan Ditjen Bimas Islam Kementerian Agama RI., 2019.

[3] B. P. Statistik, "Profil Penduduk Indonesia Hasil Supas 2015,” Jakarta: Badan Pusat Statistik, 2016.

[4] D. Lubis, Edi Chandra Juliansyah, "Aksesbilitas Penyandang Disabilitas Fisik terhadap Pekerjaan di Kelurahan Cipaisan Kecamatan Purwakarta Kabupaten Purwakarta," Biyan J. Ilm. Kebijak. dan Pelayanan Pekerj. Sos. Vol. O, vol. 2, no. 1, 2020.

[5] S. Wignjosoebroto, Hukum dalam Masyarakat Perkembangan dan Masalah Sebuah Pengantar ke Arah Kajian Sosiologi Hukum. Malang: Bayumedia Publishing, 2008.

[6] S. Soekanto, Pokok-Pokok Sosiologi Hukum. Jakarta: Raja Grafindo Persada, 2010.

[7] S. Utsman, Dasar-Dasar Sosiologi Hukum. Yogyakarta: Pustaka Lestari, 2010.

[8] M. S. Karundeng, "Penegakan Sanksi Administrasi sebagai Salah Satu Instrumen dalam Hukum Lingkungan di Indonesia," .Lex Crim., vol. V, no. 5, pp. 159-164, 2016. 